\title{
Kernos
}

Revue internationale et pluridisciplinaire de religion grecque antique

9 | 1996

Varia

\section{Organization or Religious Life in Odessos}

\section{Zlatozara Gočeva}

\section{OpenEdition}

\section{Journals}

\section{Electronic version}

URL: http://journals.openedition.org/kernos/1161

DOI: $10.4000 /$ kernos. 1161

ISSN: 2034-7871

\section{Publisher}

Centre international d'étude de la religion grecque antique

\section{Printed version}

Date of publication: 1 January 1996

ISSN: 0776-3824

\section{Electronic reference}

Zlatozara Gočeva, "Organization or Religious Life in Odessos », Kernos [Online], 9 | 1996, Online since 21 April 2011, connection on 22 April 2019. URL : http://journals.openedition.org/kernos/1161 ; DOI : 10.4000/kernos. 1161 


\section{Organization of Religious Life in Odessos}

Greek colonization of the Black Sea coast started relatively late, probably at the end of the 6 th or even in the beginning of the 6th century BC. However, Greek navigation in this region can be dated much earlier, which also implies earlier dating of the contacts of the Greeks with the local Thracian settlements there. There was likewise an early strong presence of the Thracians along the Western Pontic coast. This is clearly evident from the legend about the Thracian King Phineus who reigned over Salmydessos in the southernmost part of the Western Pontic coast. According to the legend, narrated in detail by Apollonius Rhodius in his Argonautica, it was he who helped the Argonauts move amidst the moving rocks Sempligades. ${ }^{1} \mathrm{He}$ did this in exchange for the help which the two Argonauts, the sons of Boreas -Zetes and Kalais- offered him against the Harpies who plundered his food on the orders of Zeus and as a punishment for the crime which he committed against his wife. This element in the Greek legend clearly demonstrates the power which the Thracians had over the "inhospitable sea". And bearing in mind the legend of the Greeks, perhaps it was with Thracian assistance and consent that the sea became "hospitable" to Greek navigators. ${ }^{2}$ This is also very well explained by the evidence reported by Thucydides about Thracian thalassocracy. ${ }^{3}$

According to many recent archaeological and underwater data, Thracian emporia along the coast date from a much earlier period. This is also suggested by early anchors found during these explorations. ${ }^{4}$ This also confirms very reliably the opinion in the specialized literature that the later Greek colonies along the Western Pontic coast emerged at the site of earlier Thracian settlements. ${ }^{5}$ This opinion finds support in the linguistic theories about the origin of their name. ${ }^{6}$ In that case, there is no doubt for us that the Greek colonists, who had gone there already in the late 7 th and early 6 th century $\mathrm{BC}$, were confronted with a local population with a sufficiently developed culture and religion.

\footnotetext{
1 Zl. GoČEva, Le mytbe de Pbinée et la Thrace Pontique, in Pulpudeva, 3 (1980), p. 42-46.

2 Ibidem.

3 DIOD., VII, 11.

4 B. DIMITROV and C. NICOLOV, Stone Anchors from Sosopol, in lJNA, 5 (1976), p. 81-83.

5 V. VELKOV, Mesambria, Mesemvia - Nessebre (Situation, recbercbes, notes bistoriques), in Nessebre I, Sofia, 1969, p. 15.

6 D. DETSCHEW, Die tbrakischen Spracbreste, Wien, 1976, p. 355.
} 
The first wave of colonists came without exception from Miletus, as well as in the entire region of the northern and southern Pontic coast. Apollonia (present-day Sozopol) was colonized first, followed by Histria, Tomis, Odessos (pres. Varna) and Dionysopolis (pres. Balchik). ${ }^{7}$ The second wave of colonists was from Megara, where Mesambria and Kalatis were created. ${ }^{8}$ In the beginning, the newly-emerged poleis maintained very close contacts with their metropolises. Even when later Athens intensified its influence throughout that entire region, after the conquest of the Chersonesos, that influence was still weak in the sphere of culture and even more in the evolution of the religious life in the Greek poleis along the Western Pontic coast. They preserved a number of specificities which had already been imposed and which had resulted from the contacts of these cities with the indigenous Thracian population and its religion. On the one hand, this came with certain elements which the colonists found to be already shaped in the culture of the indigenous Thracian population, both the population found in the newly-established colonies and the Thracian population in the hinterland, with which active contacts of different character were maintained. However, of particular significance here is the fact that local Thracian culture and religion developed in close contacts with Asia Minor, where the Ionian Greek culture of the metropolises Miletus and Megara took shape.

There is relatively little information about the organization and development of religious life in the Western Pontic poleis, especially during an earlier period, but nevertheless recent studies have provided sufficient evidence to form a rather satisfactory picture of its development and links with the indigenous Thracian culture. Throughout their whole existence, several elements remained, which the colonists had brought from the religion of their metropolises. This is particularly evident from the Apollo cult, which seemed to be the principal and the earliest cult in the religion of all these cities. ${ }^{9}$ Being worshipped as the patron-deity of the colonists, Apollo continued to play the same role in their new lands. In this way it found a very favourable climate for its evolution, as well as a very prominent place in the organization of the official religion of the Pontic poleis. To a certain extent this became the reason for its rather early penetration in Thracian religion and especially in the religious life of the Eastern Thracian lands. On account of many common features, it is associated with the local cult of the so-called "Thracian Horseman" and gained access to many of his sanctuaries as a syncretic cult. ${ }^{10}$ However, this is a complex and multi-faceted problem which is not the focus of the present work.

7 N. EHRHARDT, Milet und seine Kolonien, Frankfurt am Main, 1983; Fr. BILABEL, Die ionische Kolonisation, in Pbilologus Suppl. Bd. 14, Hft. 1 (1920), p. 178.

8 H. DANOV, Pontos Euxeinos, in RE, Suppl. 9 (1962), S. 1974-1077.

9 Zl. GoČEvA, Der Apollonkult in Odessos, in Studia in bonorem V. Besevliev, Sofia, 1978, p. $288-298$.

10 Zl. GoČEva, Le culte d'Apollon en Thrace, in Pulpudeva, 2 (1975), p. 96-99. 
All these specificities in the development of culture along the Western Pontic coast are particularly well manifested in Odessos, which is the principal focus of our attention here. There are several reasons for picking up Odessos. Above all, as mentioned above, it emerged in the place of an earlier Thracian settlement. Later this became very clearly perceptible in the evolution of the culture of Odessos, where a pronounced Thracian influence has been attested archaeologically and epigraphically since very early times. This had a particular effect on the shaping of its religious life, which was rich and varied, being rendered more complicated precisely by that early Thracian presence. On the other hand, irrespective of the difficulties associated with the exploration of a city like Odessos, lying entirely below a very large and densely populated modern city (pres. Varna), it is one of the best investigated Western Pontic cities on the territory of present-day Bulgaria, which has provided material for a number of publications and opinions, thus making a generalization of this type much easier and more reliable. Last but not least, one can point out also the place of Odessos among the Greek colonies along the Western Pontic coast and the intensity of its cultural and religious life, which is evident from the discovered monuments with their rich information.

Odessos was created as a colony of Miletus in the beginning of the 5th century BC and -as its name suggests and as was mentioned earlier- it appeared at the place of an ancient Thracian settlement or perhaps a settlement even more remote in time. ${ }^{11}$ The significance of that settlement is suggested by the explorations of the very rich and interesting Eneolithic necropolis, the materials of which - with their wealth and with the problems which they pose- qualify the settlement to which they possibly belonged as a rich settlement centre from that epoch, probably also maintaining extensive contacts with the entire Mediterranean region from very early times. ${ }^{12}$ Similar to all colonies of Miletus in the Pontic region, the cult of Apollo featured prominently here as one of the principal cults. ${ }^{13}$ Unfortunately, the available evidence is predominantly from the beginning of the Hellenistic Age, which is also the time to which the earliest epigraphic and numismatic materials have been dated. Apollo's image appears on the obverse of the earliest coins minted by that city as early as in the 4th century BC and was preserved as one of the most frequent images of the deity on coins. ${ }^{14}$ His temple can very reliably be defined as the principal temple in the city, though regrettably it has not yet

11 W. TOMASCHEK, Die alten Thraker 2, 2, in Sitzungbericbte d. kais. Akad. d. Wissenschaften, Bd. 28 (1893-1894), p. 57.

12 H. TODOROVA, Die Nekropole bet Vama und die sozialökonomischen Problemen am Ende des Äneolitbikums Bulgariens [bulgare], in Zeltscbrift filr Archäologie, 12 (1978), p. 87-98.

13 N. EHRHARD, op. cit. (n. 7).

14 B. PICK, Die antiken Münzen von Dacien und Moesien, II, 1910, p. 423-526. 
been reliably localized. ${ }^{15} \mathrm{M}$. Mirchev's assumption concerning the localization of an architectural fragment, most probably from the architrave of some public building, on which only the inscription Aחо $\Lambda . .$. can be read, still does not mean anything with certainty. However, close to the place where that fragment was found, other re-used fragments of decrees issued by the city's $\beta$ ov $\lambda \dot{\eta}$ к $\alpha \dot{i}$ $\delta \hat{\eta} \mu \varsigma_{\varsigma}^{16}$ have been discovered. On some of them there is a specific instruction that they should be placed in the temple of Apollo, or more briefly -in the temple of the god. Such a reference could mean only one thing: the principal deity of the city, which was known to all and did not need to be named, was the patron-deity. In this concrete case it can be assumed with a rather high degree of certainty that this was Apollo, and that the lapidary archives of Odessos were kept in his temple. Our hypothesis can also be supported by another inscription from Odessos, which represents a list of priests, the last of them being from $44-43 \mathrm{BC}$, i.e. the time to which the inscription is dated. ${ }^{17}$ Clearly that was a list of priests-eponyms. Here, too, there is a rather general reference that these were priests of the god, which again leads to the same speculations. The deity thus indicated reminds us of the case with the decree and calls for the same conclusions. Consequently, bearing all these arguments in mind, we can assume with a high degree of certainty that with Apollo as the patron-deity of the city, his priests who were probably mentioned in that list, were also eponyms of that city. ${ }^{18}$

The other possible assumption for identifying the patron-deity of the city stems from one of the decrees discovered in the city, with specific reference for the decree to be placed in the temple of the Samothracian gods. ${ }^{19}$ The cult of these deities during the Hellenistic Age spread to a certain extent in the Northern part of the Western Pontic coast, but that was an isolated phenomenon, dated to a relatively late period. Such a definition could hardly refer to them anonymously. According to $M$. Mirchev, their temple can also be localized in Odessos, moreover with a higher degree of certainty, due to the votive materials dedicated to the Kabeiroi, discovered in that place. ${ }^{20}$ The links of Odessos with the sanctuary of the Great Gods of Samothrace are also suggested by a decree discovered in their sanctuary there, containing evidence about the participation of inhabitants of Odessos in the mysteries there. ${ }^{21}$ The reference to a priest from Odessos has given grounds to L. Robert to assume that the

15 M. MIRČEV, Sur les temples antiques d'Odessos [bulgare], in Bull. du Musée archéologique de Vama, 3 (1967), p. 22.

16 G. MiHAILOV, Inscriptiones graecae in Bulgaria repertae I, Sofia, 1970, Nos 34 bis-45 bis.

17 Ibidem, No 46.

18 Zl. GoČEva, Prêtres éponymes d'Odessos et Dionysopolis, in Klio, 62, 1 (1980), p. 49-53.

19 G. MiHAilov, op. cit. (n. 16), No 42.

20 MIR $\breve{C E V}$, art. clt. (n. 15).

21 G. MHHAllov, op. cit. (n. 16), p. 92 and Lit. 
eponym mentioned as a priest (being actually absent in the inscription) must have been a priest of the Great God of Odessos as well. ${ }^{22}$ Such a claim, however, is not based on any reliable evidence. The mentioning of the priesteponym is only important as a formula for the purposes of dating. There is no evidence in the text about links between that priests and the participation of citizens of Odessos in the mysteries of Samothrace. There is even less evidence in support of the connection between the Great Gods of Samothrace and the cult of the Great God of Odessos. It is even less justified to claim that at least by the end of the Hellenistic Age his cult was imposed as the principal cult of the city, replacing the Apollo cult.

The situation was quite different during the Roman period, when after very serious changes in the religious life of the city and with the penetration of a strong Thracian influence into the religion of Odessos, the Great God of the people of Odessos was associated with the Thracian deity Darzalas. ${ }^{23}$ The deity himself was mentioned as an eponym in genitivus absolutus in several ephebian decrees from the beginning of the 2nd century AD, parallel with the dating according to the consuls in the Roman fashion, possibly as a manifestation of attention towards this Thracian cult. ${ }^{24}$ In an inscription on a tomb erected as an

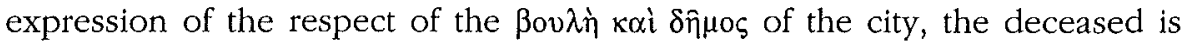
referred to as vewxópos of Theos Megas Darzalas. ${ }^{25}$ In spite of the very clear inscription which can be read very reliably, Professor Georgi Mihailov expressed certain doubts about its interpretation, probably due to the rather unusual use of that definition for that late epoch. Apparently, this is not a case of the use of the term neocoria in its usual Roman connotation, but rather a much older Greek tradition of the use of the title not in connection with the cult of the Emperor, but as a servant of the cult of Theos Megas Darzalas. It is possible that the priest received the title personally for some merit to the city. The explanation of such a deviation from the usual use can be sought perhaps in this specific character of religious life of Odessos during the Roman period, due to the special status of the Greek poleis within the outlines of a western-type province like Moesia Inferior.

An evidence of this complex evolution of religion in Odessos, especially during the Late Hellenistic Age, can be seen in the earliest appearance precisely here of the cult of the Thracian Horseman -in the city itself and in its immediate surroundings. According to some studies, Odessos was precisely the region in which the iconographic pattern of this Thracian deity was formed and

22 L. ROBERT, Divinités éponymes, in Hellenica, II (1946), p. 50-64.

23 Zl. Gơ̌Eva, Der Kult des Teos Megas Darzalas in Odessos, in Wilrzburger Jabrb. f. die Altertumstissenschaft, 7 (1981), p. 229-234.

24 G. MiHAILOV, op. cit (n. 16), Nos 47, 47bis, 48.

25 Ibidem, No 230bis. 
later spread all over Thrace. ${ }^{26}$ On the other hand, it is very interesting to note the very sophisticated iconographic system of his monuments in Odessos and the adjacent region, as well as the strong influence of that iconography on the formation of a group of sepulchral monuments in the region, which are very closely connected iconographically with those of the Thracian Horseman. ${ }^{27}$ One of the biggest sanctuaries dedicated to the Heros with the epithet Karabasmus is located in the immediate vicinity of the city of Varna -in the Galata locality. It was precisely there that the earliest monuments were discovered, dated according to some researchers to the Hellenistic Age. ${ }^{28}$ According to a number of epigraphic data and above all from names of dedicators, it is becoming clear that there existed a very close connection between the sanctuary and the

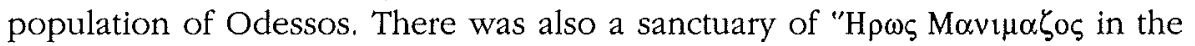
city, as well as an association of the worshippers of his cult, and of the cult of

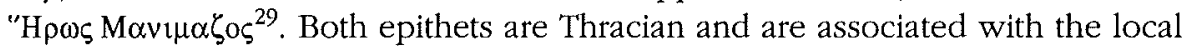
cult of the Thracian horseman, which penetrated and found its place in the religious life of the Greek polis.

The Pontic pentapolis, which existed and played an important role in the administrative structure of the Roman province of Moesia Inferior, was probably created during the Late Hellenistic Age. ${ }^{30}$ The pentapolis comprises the five cities in the northern part of the Western Pontic coast (for a while it was a hexapolis with six cities). Within the frameworks of the Roman administrative unit, such as the province, it succeeded in preserving certain features of the structure of the administrative and religious life characteristic of the East. The

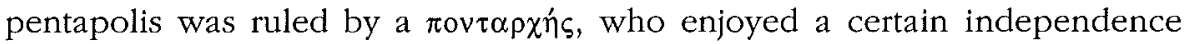
within the confines of the province. ${ }^{31}$ The religious life was subordinated to an

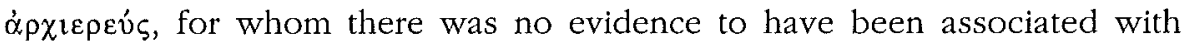
sacerdos provinciae, or at least enjoyed a certain autonomy with respect to the organizing of the religious life in the Greek polets. The practising of the Emperor's cult was probably also entrusted to him. According to a number of data, at least in the first years of the existence of the pentapolis, Odessos was its metropolis and the centre of the organization of its religious life, in addition

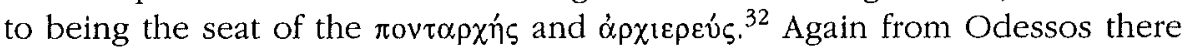
is evidence about a post which existed only in that region - $\varepsilon \ddot{v} \pi \circ \sigma$ óó $\rho \chi \eta \varsigma$ -

26 G. TONČEvA, Sur l'iconograpble et le caractère du Cavalier thrace d'Odessos [bulgare], in Acta antiqua Pbilippopolitana, Studia arch. (1963), p. 71-74.

27 Zl. GOČEVA und M. OPPERMANN, Corpus cultus Equitis Thracii, I, Leiden, 1974 (EPRO, 74).

28 G. MiHAILOV, op. cit. (n. 16), Nos 283-294.

29 Ibidem, Nos 77, 78, 78ter.

30 G. KAZAROW, Zur Gescbicbte des linkspontiscben Koinonin, in Klio, 9 (1909), p. 492-439.

31 G. MiHallov, The Western Pontic Koinon, in Epigraphica, 41 (1979), p. 7-42.

32 Zl. Gơ̌EvA, Einige Bemerkungen zum Problem der Metropolia des Westpontiscben Koinon, in Terra Antiqua Balcanlca II, 1987, Tirnovo, p. 247-250. 
which meant, according to most researchers, qui symposia sacra curat..$^{33}$ The fact that this post existed only in Odessos and later in Tomis, which is indicated as the later metropolis of the pentapolis, gives grounds to associate it with the organization of religious life there. It also emphasizes its independent religious life of a Pontic koinon, perpetuating the traditions of the Greek polis and taking into account the indigenous traditions.

From the still not very numerous epigraphic and archaeological data it is possible nevertheless to present a generalized characterization of the organization of religious life in Odessos, which was very intricate and rich in various religious manifestations. This fully corresponds to the complicated picture of the historical development of Odessos which emerged as the centre of an early developed culture ever since the Eneolithic age. It existed as a Thracian settlement and passed into a Greek Ionian-Anatolian colony with a Thracian hinterland with a rich spiritual life. The city developed a sophisticated Hellenistic culture precisely under the influence of that hinterland that had become the centre of the Pontic koinon during the Late Hellenistic Age, and above all within the confines of the Roman Empire.

34, ul. Koslodui

Zlatozara GočEVA

SOFIA 1202

Bulgaria

33 G. MiHAIlov, op. cit. (n. 16), No 167 and comm. 